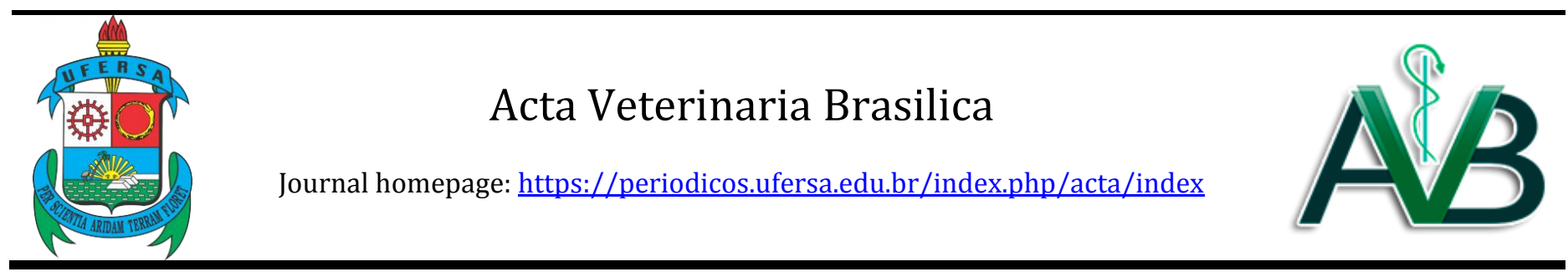

Original Article

\title{
Use of vegetable charcoal as an alternative to the composition of broiler litter
}

\author{
Daniel Couto de Brito ${ }^{1}$, Luciana Kazue Otutumi2, Lucas de Almeida Reati ${ }^{3}$, Jean Marcos de Morais Oliveira ${ }^{3}$, \\ Maira Rodrigues Dourado'1, Ranulfo Piau Júnior² \\ ${ }^{1}$ Mestre em Ciência Animal pela Universidade Paranaense, Unipar. \\ 2 Professor (a) do curso de Medicina Veterinária e do Programa de Pós-Graduação em Ciência Animal com Ênfase em Produtos Bioativos \\ da Unipar. \\ ${ }^{3}$ Acadêmico do curso de Medicina Veterinária, bolsista PIBIC/UNIPAR.
}

\section{A R T I C L E I N F O}

\begin{tabular}{l} 
Article history \\
Received 15 May 2017 \\
Received in revised form 19 September \\
2017 \\
Accepted 27 September 2017 \\
\hline
\end{tabular}

Keywords:

Feed Conversion

Histopathological lesions

Animal comfort

Productive Performance

Residue Charcoal

\section{INTRODUCTION}

Poultry production reached 12.900 million tons in 2016 , presenting a $1.82 \%$ reduction when compared to 2015 (ABPA, 2017). These numbers turn Brazil into the largest global exporter and the second largest poultry producer in the world (AVISITE, 2017), showing that poultry meat is one of the animal protein sources in expansion.

The prominent position of the Brazilian poultry production is due to the modernization of the broiler production chain as a consequence of the genetic improvement and advances in nutrition, sanitation and bird management areas aiming at not losing competitiveness at a global level by reducing costs and increasing productivity.

The use of litters in broiler aviaries has the purpose of avoiding the direct contact of the birds with the floor, being used as a substrate for absorbing the environmental moisture, incorporating excreta, feathers, skin shedding and feed waste falling from feeders, as well as contributing to reducing the thermal insulation within the poultry farm (AVILA; MAZZUCO; FIGUEIREDO, 1992).

Additionally, Angelo et al. (1997) emphasized that the use of broiler litters has the purpose of providing

*Corresponding author: danielcoutobrito@hotmail.com 
comfort to the birds, since the animals can express their natural scratching and foraging behavior, allowing them to express their genetic potential and decreasing the index of breast, leg and foot pad lesions, as well as attenuating the negative impacts imposed on broilers in industrial chicken farming, mainly in high density environments.

Charcoal chaff is an alternative material for broiler litter. According to Brito et al. (2012), Brazil is the largest global producer of charcoal, and its production can be found throughout the country. This product is specifically used for obtaining heat for pig iron taping, the raw material for steel. Since it is very friable, charcoal produces a lot of thin shedding due to its breaking during production, transport and handling. Such shedding can reach up to $20 \%$ of the total amount produced. This thin shedding is known as charcoal chaff or "moinha" (MELO et al., 2005), and is usually discarded.

Therefore, considering the lack of use for charcoal chaff, the purpose of this paper was to assess the performance and quality of it being used as litter, as well as the health of broilers raised on charcoal chaff litters.

\section{MATERIALS AND METHODS}

The experiment was developed at the Experimental Aviary in the Veterinary Hospital at Universidade Paranaense, in the city of Umuarama, located in the northwestern region of the state of Paraná (latitude $23^{\circ}$ $46^{\prime} 00.19$ "and longitude $53^{\circ} 16^{\prime} 26.39^{\prime \prime}$ ), with an average height of 445 meters above sea level, from October to December 2014. This experiment was approved by the Ethics and Research Involving Animal Experimentation Committee (CEPEEA) from that University under protocol No. 25122/2014.

A total of 225 Cobb 500 (Gallus gallus) broiler chicks were distributed in an entirely random design, with three treatments: $\left(\mathrm{T}_{1}=\right.$ broiler chicks housed in wood shaving litter; $\mathrm{T}_{2}=$ broiler chicks housed in $50 \%$ wood shaving and $50 \%$ charcoal processing waste (chaff); $\mathrm{T}_{3}=$ broiler chicks housed in charcoal processing waste) with five repetitions each, in a total of 15 experimental units.

The birds were housed in masonry sheds with concrete floors, comprising of 15 boxes measuring $2.775 \mathrm{~m}^{2}(1.85$ $\mathrm{x} 1.5 \mathrm{~m}$ ) each, with a pending drinking fountain and a tube feeder placed in each unit. During the initial breeding phase, infant feeders and drinking fountains were provided, as well as heating with infrared light. The light program performed in the experiment was 24 hours of light during the first week, and 16 hours of light from the second week until the slaughtering of the birds. The litter was daily management with a fork, and there was no need to replace or exchange any material during the experiment.

The feed used was formulated according to the feed composition proposed by Rostagno et al. (2011) to meet the nutritional demands of broilers in each breeding phase (pre-initial, initial, growth and final), and provided in meal form throughout all phases. It also included performance enhancers as shown on Table 1.

Table 1. Centesimal and nutritional composition of experimental feeds for broilers in pre-initial, initial, growth and final phases

\begin{tabular}{|c|c|c|c|c|}
\hline \multirow{2}{*}{ Ingredient } & \multicolumn{4}{|c|}{ Centesimal composition (\%) } \\
\hline & Pre-initial & Initial & Growth & Final \\
\hline Corn & 58 & 59 & 65 & 69 \\
\hline Soybean meal & 37 & 36 & 30 & 26 \\
\hline Nucleus* & 05 & 05 & 05 & 05 \\
\hline \multirow[t]{2}{*}{ TOTAL } & 100 & 100 & 100 & 100 \\
\hline & \multicolumn{4}{|c|}{ Nutritional composition } \\
\hline Metabolizable Energy (kcal/kg) & 2,849 & 2,856 & 2,921 & 2,954 \\
\hline Crude Protein (\%) & 21.42 & 20.97 & 18.74 & 17.22 \\
\hline Total calcium (\%) & 0.96 & 0.81 & 0.77 & 0.74 \\
\hline Available phosphorous (\%) & 0.45 & 0.43 & 0.40 & 0.38 \\
\hline Total lysine (\%) & 1.23 & 1.19 & 1.03 & 0.92 \\
\hline Total Methionine + Cystine (\%) & 0.91 & 0.84 & 0.73 & 0.60 \\
\hline Total tryptophan (\%) & 0.29 & 0.28 & 0.25 & 0.22 \\
\hline
\end{tabular}

* Nucleus (Tectron, Toledo, PR, Brazil) containing salt, limestone, dicalcium phosphate, DL-methionine, vitamin-mineral premix**, enzymes (xylanase, cellulase, protease, $\beta$-glucanase, amylase and phytase), halquinol (antibiotic) and salinomycin (anticoccidial).

** The vitamin and mineral premix contain the following ingredients per kg of diet: pre-initial and initial: vit. A, 7000 UI; vit. D3, 2000 UI; vit. E, 11 UI; vit. K3 2 mg; vit. B1, 2 mg; vit B2, 5 mg; vit. B6, 2 mg; vit. B12, 10 ug; niacin, 35 mg; pantothenic acid 12 mg; folic acid 1 mg; biotin, 40 mg; manganese, 60 ppm; zinc 50 ppm; iron, 40 ppm; copper, 8 ppm; iodine, 1 ppm; selenium, 0.3 ppm; growth: vit. A, 5500 UI;

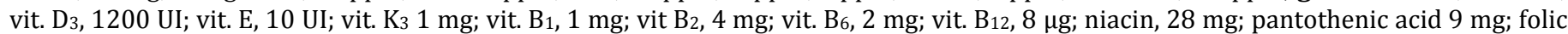
acid $1 \mathrm{mg}$; biotin, $40 \mathrm{mg}$; manganese, 60 ppm; zinc 50 ppm; iron, 40 ppm; copper, 8 ppm; iodine, 1 ppm; selenium, 0.3 ppm; final: vit. A,

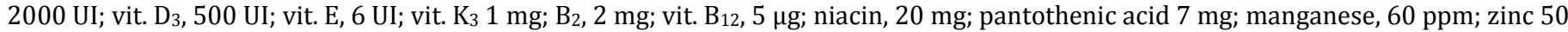
ppm; iron, 40 ppm; copper, 8 ppm; iodine, 1 ppm; selenium, 0.3 ppm. 
The broiler performance was assessed on a weekly basis during the six breeding weeks through the determination of feed consumption (g), weight gain (g), and feed conversion (g/g). Feed conversion was calculated by the ratio between feed consumption and weight gain for each period.

The litter was collected for the analysis of moisture, ashes, phosphorous and nitrogen content at 41 days. The litter collection was performed in three points within each box, avoiding the areas near and below the feeders and drinking fountains (CRUZ et al., 2013). The samples were homogenized and packaged for later analysis.

Before the execution of the experiment, the water absorption of the material (chaff and shavings) was performed according to the methodology described by Potgieter; Wilke (1996), and the evaporation rate was evaluated by keeping the material in a forced ventilation oven at a temperature of $65^{\circ} \mathrm{C}$ for two hours. The results demonstrated that the shavings absorb seven-fold more water than the chaff; however, the evaporation rate is similar (57 vs $59 \%$ ).

The methodology described by Silva; Queiroz (2002) was used for dry matter, ashes and nitrogen content, which were processed in the Agricultural Microbiology Laboratory at Universidade Paranaense.

Phosphorous content was determined by the colorimetric method using a spectrophotometer, according to methodology described by Malavolta; Boaretto; Paulino (1991).

At the end of the experimental period (41 days), trachea and lung samples were collected for histopathological assessment. For that purpose, one animal from each experimental unit was submitted to euthanasia using an anesthetic protocol (xylazine (Syntec, Hortolândia, SP, Brazil) as a pre-anesthetic medication at an intramuscular dose of $4 \mathrm{mg} / \mathrm{Kg}$ and euthanasia with sodium thiopental (Cristália, Itapira, SP, Brazil) at a 25 $\mathrm{mg} / \mathrm{Kg}$ dose). The samples were fixed in $10 \%$ formalin for a minimum of 24 hours and then, the material was prepared for analysis. The material was cut and went through dehydration in increasing alcohol series. Then, the samples were diaphanized in xylol and included in paraffin according to methodology described by Beçak; Paulete (1976). Semiseriated cuts $(5-\mu \mathrm{m})$ were obtained and were later stained using the hematoxylin and eosin technique. The interstitial thickening, presence of inflammatory infiltrate and necrosis were assessed in the lung. Ciliary loss, globet cell hypertrophy, epithelial peeling and presence of inflammatory infiltrate were assessed in the trachea.

Performance parameters (feed consumption, weight gain and feed conversion) were assessed for the three growth phases (initial: one to seven days of age; development: one to 21 days of age; final: 21 to 41 days of age) and in the total animal breeding period (one to 41 days of age). The litter assessments ( $\%$ dry matter, \% ashes, \% phosphorous and \% nitrogen) were first analyzed in relation to their normality (Shapiro-Wilk assay) and variance homogeneity (Levene assay). After confirming the normality of data and variance homogeneity, the studied parameters were submitted to an analysis of variance (ANOVA). When applicable, Tukey's test was performed for comparing the means, after the identification of significant differences between treatments in ANOVA. Statistical data were obtained using the IBM SPSS v. 21.0 program. A 5\% significance level was considered for all assays.

\section{RESULTS}

No differences were found among the treatments for performance variables (weight gain (g), mean feed consumption (g) and feed conversion $(\mathrm{g} / \mathrm{g})$ ) for broilers raised or not on litters with $50 \%$ or $100 \%$ vegetable charcoal chaff in the period of one to seven, one to 21,21 to 41 , and one to 41 days of age (Table 2 ).

The litter ash, nitrogen and phosphorous percentages were not influenced by the treatments $(p>0.05)$ (Table $3)$. In relation to the dry matter percentage, a greater percentage $(p<0.05)$ of dry matter was observed for the litter with $100 \%$ CC when compared to the control treatment (100\% wood shaving) (Table 3 ).

No changes were observed regarding histopathological analyses (trachea and lung). No interstitial thickening, inflammatory infiltrate or necrosis was found in the lung. No ciliary loss, globet cell hypertrophy, epithelial scaling and inflammatory infiltrate were identified in the trachea (Figure 1).

\section{DISCUSSION}

Considering the poultry production figures of 12.900 million tons (ABPA, 2017), it is estimated that approximately 5.076 million broilers have been housed. Additionally, the current Brazilian poultry production houses approximately 12 birds per square meter, thus needing 70.5 million square meters. Therefore, the modern poultry farming uses approximately $10 \mathrm{~kg}$ aviary litter per square meter of broiler production. Therefore, it is estimated that the Brazilian broiler production needed approximately 705 thousand tons of aviary litter substrate in 2015, which demonstrates its high demand in the production of commercial broilers.

Different materials are currently being used as broiler litter. However, each of them presents variations regarding its greater or lower moisture absorption capacity and it ability to provide comfort to the animals. 
Avila et al. (2007) reported six main litter sources in substitution to wood shavings: rice husks, shredded corncobs, chopped Cameron grass, chopped soybean husks, chopped corn crop residues and sawdust. According to those authors, the availability of appropriate material for the preparation of broiler litter is not always satisfactory, since it demands its transportation from other regions, thus increasing production costs.

Table 2. Mean \pm standard error for weight gain (g), mean feed consumption (g) and feed conversion (g/g) for broilers raised on litters originated from vegetable charcoal chaff in the periods of one to seven, one to 21,21 to 41 , and one to 41 days of age.

\begin{tabular}{|c|c|c|c|}
\hline Treatments & Weight gain (g) & Mean feed consumption (g) & Feed conversion $(\mathrm{g} / \mathrm{g})$ \\
\hline & \multicolumn{3}{|c|}{ one to seven days of age } \\
\hline Control & $140.20 \pm 2.55$ & $178.45 \pm 7.57$ & $1.32 \pm 0.035$ \\
\hline $50 \%$ wood shaving: $50 \%$ chaff & $137.03 \pm 3.42$ & $176.62 \pm 4.18$ & $1.30 \pm 0.029$ \\
\hline $100 \%$ chaff & $139.24 \pm 3.01$ & $180.28 \pm 6.07$ & $1.27 \pm 0.028$ \\
\hline \multirow[t]{2}{*}{ P value* } & 0.7554 & 0.9140 & 0.5417 \\
\hline & \multicolumn{3}{|c|}{ one to 21 days of age } \\
\hline Control & $818.67 \pm 9.99$ & $1222.64 \pm 21.82$ & $1.51 \pm 0.013$ \\
\hline $50 \%$ wood shaving: $50 \%$ chaff & $809.42 \pm 8.81$ & $1230.02 \pm 13.11$ & $1.52 \pm 0.007$ \\
\hline $100 \%$ chaff & $815.52 \pm 16.11$ & $1247.04 \pm 17.48$ & $1.53 \pm 0.037$ \\
\hline \multirow[t]{2}{*}{ P value* } & 0.8607 & 0.6274 & 0.8870 \\
\hline & \multicolumn{3}{|c|}{21 to 41 days of age } \\
\hline Control & $1631.75 \pm 7.02$ & $3256.04 \pm 4.38$ & $1.99 \pm 3.00$ \\
\hline $50 \%$ wood shaving: $50 \%$ chaff & $1670.91 \pm 3.24$ & $3325.51 \pm 3.72$ & $1.99 \pm 1.53$ \\
\hline $100 \%$ chaff & $1646.69 \pm 3.16$ & $3266.85 \pm 3.14$ & $1.98 \pm 1.95$ \\
\hline \multirow[t]{2}{*}{ P value* } & 0.7409 & 0.6504 & 0.8753 \\
\hline & \multicolumn{3}{|c|}{ one to 41 days of age } \\
\hline Control & $2450.43 \pm 57.22$ & $4478.69 \pm 80.66$ & $1.969 \pm 0.015$ \\
\hline $50 \%$ wood shaving: $50 \%$ chaff & $2480.33 \pm 27.74$ & $4555.53 \pm 56.82$ & $1.963 \pm 0.010$ \\
\hline $100 \%$ chaff & $2462.21 \pm 27.62$ & $4514.00 \pm 37.62$ & $1.953 \pm 0.014$ \\
\hline P value* & 0.8692 & 0.6846 & 0.707 \\
\hline
\end{tabular}

* Not significant by ANOVA.

Table 3. Mean \pm standard error for dry matter, ash, nitrogen and phosphorous percentages of broiler litters (control, 50\% wood shaving (WS) and 50\% charcoal chaff (CC), and 100\% charcoal chaff at the end of the experimental period (41 days).

$\begin{array}{lllll}\text { Treatments } & \text { Dry matter } & \text { Ash } & \text { Nitrogen }\end{array}$

Percentage

\begin{tabular}{ccccc}
\hline Control & $68.718 \pm 3.058^{\mathrm{b}}$ & $12.716 \pm 1.43$ & $2.706 \pm 0.134$ & $1.303 \pm 0.097$ \\
$50 \%$ WS: $50 \%$ CC & $75.457 \pm 1.714^{\mathrm{ab}}$ & $11.915 \pm 1.197$ & $2.786 \pm 0.057$ & $1.225 \pm 0.098$ \\
$100 \%$ CC & $78.759 \pm 1.477^{\mathrm{a}}$ & $11.929 \pm 0.643$ & $2.496 \pm 0.104$ & $1.072 \pm 0.089$ \\
P Value & 0.0206 & 0.8526 & 0.1625 & 0.2507 \\
\hline
\end{tabular}

Means followed by different letters in the column are statistically different by Tukey's test; 
Figure 1. Lung (A) (40X magnification) and trachea photomicrography (B) (400X magnification) of broilers at 41 days of age raised on litter originated from charcoal processing waste (chaff). The arrow in (A) indicates lung alveoli with no changes (thickening, inflammatory infiltrate or necrosis). The arrow in (B) indicates normal trachea epithelium with no ciliary loss and globet cell hypertrophy, epithelial scaling or the presence of inflammatory infiltrate. 1 - Control treatment; 2 - Treatment with 50\% WS: 50\% CC; 3 - Treatment with 100\% CC. (HE Dying).

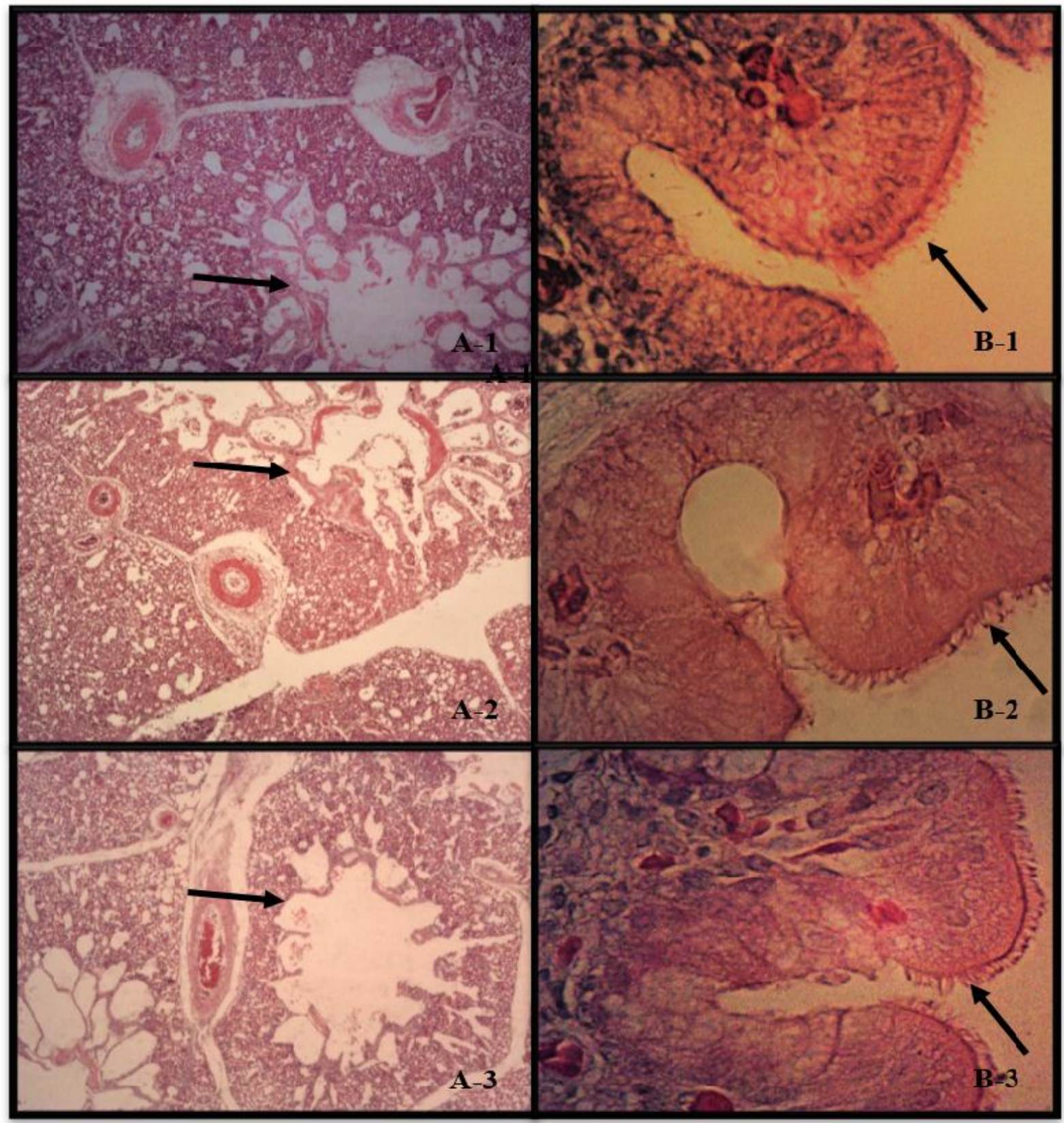

Source: Author's collection.

The use of charcoal chaff as broiler litter has not significantly influenced the performance of broiler chicken (Table 2), showing it is possible to use such material as an alternative for the composition of broiler litter. This material is widely available and well distributed throughout the national territory, with its cost being almost insignificant in relation to wood shaving, and in many cases, even offered free of charge.

Although vegetable charcoal presents physical characteristics that could suggest a hypothesis of carcass pigmentation, difficult handling during the production or muscle injuries, none of these characteristics were presented in the study, and after slaughtering, the consumers were not able to classify in which treatments the birds were produced.

The rerouting or reusing of the litter was not evaluated due to the time and cost constraints of the experiment, but further analyzes on the reuse or reassembly of the litter should be performed over time to understand the 
effect of increasing the ratio of organic matter (feces) to vegetal charcoal.

In general terms, the published papers have shown that the material used as poultry litter does not directly influence the poultry body weight, but in practical commercial terms, there are material standards that allow greater thermal comfort for birds and provide them with the opportunity to express animal wellbeing behaviors, which could indirectly influence the body weight, feed consumption and feed conversion.

Navneet et al. (2011) demonstrated that the type of material used (rice husks, chopped rice chaff, nonchopped rice chaff) does not affect the body weight or other zoo technical results (weight gain, feed consumption and feed conversion), corroborating with the results found herein.

Similar results were found by Davis et al. (2010) (wood shavings and chopped grass) and Sharma et al. (2015) (rice husks, rice chaff, pine wood shaving and a combination of wood shaving and rice husk), where no significant difference was observed ( $p>0.05)$ in zoo technical results, such as body weight, feed consumption and feed conversion.

On the other hand, the study by Mahmoud et al. (2014) demonstrated that the animals raised in sand litter present higher body weight and, according to Villagrá et al. (2014), this is related to the preference of expressing comfort behavior. According to the authors, the birds prefer sand to other materials (rice husks and wood shaving) since it allows them to bathe in the sand, a body expression that is directly connected to the animal's wellbeing.

The ash, nitrogen and phosphorous percentage results demonstrated that the charcoal chaff has little influence on their percentage on broiler litters at the end of the experimental period (41 days) (Table 3).

Regarding nitrogen, phosphorous and potassium percentages on the litter, Sharma et al. (2015) demonstrated that the material used as litter (rice chaff, rice husks and pine wood shaving) has not interfered in the percentages after farming of a broiler batch.

Regarding the higher moisture percentage (Table 3) in the control treatment when compared to the $100 \%$ CC treatment, this might be due to the material used in the control treatment (pine wood shavings) having a higher amount of material favorable to decomposition in relation to the charcoal chaff, since chaff is already in the second decomposition stage due to the pyrolysis stage performed in the production of charcoal, which should reduce the moisture retained on the material.
Moreover, when comparing the water absorption index of the CC and the WS in the laboratory, taking into account the volume occupied and not the weight of the litter, the WS absorbed seven-fold more water than the CC, which could justify its highest moisture.

Similarly to the results in this paper, Garcês et al. (2013) have also observed a higher moisture rate in wood shaving litters when compared to sand litters.

On the other hand, the WS has an advantage in relation to CC when taking into account its greater water absorption capacity.

The results from the histopathological analysis show that even though the chaff presented a greater amount of fine particles, it has not caused changes to the respiratory tract of broilers at 41 days of age, even in treatments with charcoal chaff presenting a higher amount of visible fine particles in the daily handling and sanitation of drinking fountains and feeders, since charcoal chaff has greater amounts of fine particles when compared to wood shavings.

Although there is a study reporting injuries to the respiratory tract (DAVID et al., 2015), most of them are related to the ammonia and gases produced by fermentation as the cause of such injuries, and not associated to particles from the material used as broiler litter.

Due to the results observed in this study, it can be stated that charcoal chaff can be used as a total or partial substitute to wood shavings, maintaining the broiler performance. This is extremely valuable, since this material is more abundantly available and more feasible in many broiler production regions than wood shavings. The use of charcoal chaff in commercial poultry farming can be disclosed for producers that aim to decrease their production costs. However, charcoal chaff is not easily managed due to the amount of fine particles, its physical aspect and it would need a high amount to be used in commercial poultry farms (approximately 20 tons per $2.100 \mathrm{~m}^{2}$ farm). Therefore, it is recommended that charcoal chaff be used as a supplement for wood shaving or rice husks as a secondary litter source in order to help in liquid retention, decrease in fermentation and improvement of dry material as a fertilizer.

It is important to emphasize that the animals raised on charcoal chaff litter do not present any type of injury to feet pads that could justify it not being used as an alternative material for broiler litter.

\section{CONCLUSION}

In the conditions this experiment has been developed, it can be concluded that it is possible to use charcoal chaff as broiler litter, since it has not affected the broiler 
performance and has not caused injury to the birds' respiratory tract. However, further research is necessary on the use of charcoal chaff in order to determine important aspects, such as microbiological proliferation in the material used, effects of using the material in several broiler batches and the production of toxic gases on reused litters.

\section{ACKNOWLEDGMENTS}

The authors would like to thank Universidade Paranaense - UNIPAR, the Executive Board of Directors for Research and Post-Graduation (DEGPP) for the financial support granted, and the entire team at the Veterinary Hospital for having provided the facilities for the experiment.

\section{REFERENCES}

ABPA - Associação Brasileira de Proteína Animal. Relatório Anual ABPA 2016. Disponível em: <http://abpabr.com.br/storage/files/3678c_final_abpa_relatorio_anual_2016_portu gues_web_reduzido.pdf> Acesso em: 10 jul. 2017.

ANGELO, J.C. et al. Material de cama: qualidade, quantidade e efeito sobre o desempenho de frango de corte. Revista Brasileira de Zootecnia, v. 26, n. 1, p. 121-130, 1997.

AVILA, V.S. de et al. Valor agronômico da cama de frangos após reutilização por vários lotes consecutivos. Concórdia: EMBRAPACNPSA, 2007. 4p. (EMBRAPA-CNPSA. Comunicado técnico, 466).

AVILA, V. S. de; MAZZUCO, H.; FIGUEIREDO, E. A. P.de. Cama de aviário: materiais, reutilização, uso como alimento e fertilizante. Concórdia: EMBRAPACNPSA, 1992. 38p. (EMBRAPA-CNPSA. Circular Técnica, 16).

AVISITE. A revista do Avisite. 2017. Disponível em: <http://avisite.com.br/index.php?page=noticias\&id=17901 > Acesso em: 10 jul. 2017.

BEÇAK, W.; PAULETE, J. Técnicas de citologia e histologia. Rio de Janeiro: Livros Técnicos e Científicos; 1976.

BRITO, J.O. et al. Produção de carvão vegetal no Brasil e o atual estágio das tecnologias para aproveitamento dos gases do processo. 2012. Disponível em:< http://www.ciflorestas.com.br/arquivos/d_n_n_8674.pdf>. Acesso em: 09 Jul. 2013.

CRUZ, D.P. et al. Performance, carcass yield and litter quality of broilers raised on litters treated with micro-organisms. Ciência Animal Brasileira, v. 14, n. 1, p. 41-48, 2013.

DAVID, B. et al. Air quality in alternative housing systems may have an impact on laying hen welfare. part II- ammonia. Animals, n. 5, p. 886896, 2015.

DAVIS, J.D. et al. Evaluation of chopped switch grass as a litter material. International Journal of Poultry Science, v. 9, n. 1, p. 39-42, 2010.

MAHMOUD, M.S.H. et al. Effect of different types of litter on broiler performance. Research Journal Poultry Science, v. 7, n. 1, p 1-6, 2014.

MALAVOLTA, E.; BOARETTO. A.; PAULINO, V.T. Micronutrientes, uma visão geral. In: FERREIRA, M.E.; CRUZ, M. C. Micronutrientes na Agricultura. Piracicaba: Potafós/CNPq. 1991. p. 1-33.
MELO, F.A.O. et al. Avaliação de uma fornalha para aquecimento direto de ar utilizando moinha de carvão. Engenharia na Agricultura, v. 13, n. 2, p. 124-129, 2005.

NAVNEET, K. et al. Paddy straw as an alternate bedding material for broiler chicks. Journal World's Poultry Research, v. 2, n. 3, p. 48-53, 2011.

POTGIETER, F. J.; WILKE, P. I. The dust content, dust generation, ammonia production, and absorption properties of three different rodent bedding types. Laboratory Animals, v. 30, n. 1, p. 79-87, 1996.

ROSTAGNO, H. S. et al. Tabelas brasileiras para aves e suínos: composição de alimentos e exigências nutricionais. Viçosa, MG: Universidade Federal de Viçosa, 2011. 141p.

SHARMA, G. et al. Efficacy of pine leaves as an alternative bedding material for broiler chicks during summer season. Veterinary World, v. 8, p 1219-1224, 2015.

SILVA, D. J.; QUEIROZ, A. C. Análise de alimentos: métodos químicos e biológicos. 3.ed. Viçosa: UFV, 2002. 235p.

VILLAGRÁ, A. et al. Behavior of broiler chickens in four different substrates: a choice test brazilian. Journal of Poultry Science, v. 16, n. 1, p 67-76, 2014. 